\title{
Sheep polyclonal antibody to map Haemonchus contortus mimotopes using phage display library
}

\author{
Anticorpo policlonal de ovinos para mapear mimetopos de Haemonchus contortus usando a \\ biblioteca de Phage display
}
Andréia Buzatti ${ }^{1+*}$; Arnielis Diaz Fernandez ${ }^{2+}$; Amilcar Arenal2²; Erlán Pereira²; Alda Lucia Gomes Monteiro³ Marcelo Beltrão Molento ${ }^{1}$

\begin{abstract}
${ }^{1}$ Laboratório de Doenças Parasitárias, Departamento de Medicina Veterinária, Universidade Federal do Paraná - UFPR, Curitiba, PR, Brasil
${ }^{2}$ Facultad de Ciencias Agropecuarias, Universidad de Camagüey Ignacio Agramonte Loynaz, Camagüey, Cuba

${ }^{3}$ Laboratório de Produçáo e Pesquisa em Ovinos e Caprinos, Departamento de Zootecnia, Universidade Federal do Paraná - UFPR, Curitiba, PR, Brasil

+These authors contributed equally to this work.
\end{abstract}

Received November 14, 2017

Accepted March 9, 2018

\begin{abstract}
The aim of this study was to evaluate phage display technology for mapping Haemonchus contortus mimotopes. We screened the PhD-7 Phage Display Peptide Library Kit with a sheep polyclonal antibody against $H$. contortus. After four rounds of selection, 50 phage peptide clones were selected by biopanning and sequenced. Two clones displaying peptide mimotopes of $H$. contortus proteins were chosen for sheep immunization: clone 6 - mimotope of glyceraldehyde-3-phosphate dehydrogenase (GAPDH) and clone 17 - mimotope of a disorganized muscle family member (Dim 1). Twelve sheep were allocated into 3 groups of 4 animals as follow: G1: control group; G2/GAPDH: immunized with clone 6; and G3/Dim1: immunized with clone 17. Four immunizations were performed at intervals of seven days $(0,7,14$, and 21 days). On day 28 post initial vaccination, all groups were orally challenged with $2500 \mathrm{H}$. contortus infective larvae. The mimotope peptides selected by phage display were recognized by IgG from sheep naturaly infected with $H$. contortus. The immunization protocol showed an increasein IgG anti-M13 phage titers, but no effect was observed in IgG-specific for the anti-mimotope peptides. This is the first report of successful use of a phage display library for the identification of mimotopes of $H$. contortus proteins.
\end{abstract}

Keywords: Mimotopes, biopanning, ELISA, ruminants, immunogenic.

\section{Resumo}

O objetivo deste estudo foi avaliar a tecnologia de phage display no mapeamento de mimetopos de Haemonchus contortus. Anticorpo policlonal de ovinos anti-H. contortus foi usado para seleção a partir da biblioteca PhD-7 Phage Display Peptide Library Kit (New England BioLabs). Após quatro rodadas, 50 clones de fagos expressando peptídeos foram selecionados e sequenciados. Dois clones que exibiram mimetopos de $H$. contortus foram escolhidos para imunização de ovinos: clone 6 - mimetopo de gliceraldeído-3-fosfato desidrogenase (GAPDH) e clone 17 - mimetopo da família do músculo desorganizado (Dim 1). Doze ovinos foram alocados em 3 grupos de 4 animais, da seguinte forma: G1: grupo controle, G2/GAPDH: imunizado com o clone 6 e G3/Dim1: imunizado com o clone 17. Quatro imunizaçóes foram realizadas $(0,7,14$ e 21 dias). No dia 28 após a primeira imunização, todos os grupos foram desafiados oralmente com 2500 larvas infectantes de $H$. contortus. Os peptídeos mimetopos selecionados foram reconhecidos por IgG de ovinos naturalmente infectados por $H$. contortus. O ensaio de imunizaçáo revelou um aument dos títulos de IgG anti-fago M13, mas náo ocorreu aumento de IgG anti-peptídeos mimetopos. Este é o primeiro relato de uso bem sucedido da biblioteca de Phage display para a identificação de mimetopos de H. contortus.

Palavras-chave: Mimetopos, biopanning, ELISA, ruminantes, imunogênicos.

\footnotetext{
${ }^{*}$ Corresponding author: Andréia Buzatti. Laboratório de Doenças Parasitárias, Departamento de Medicina Veterinária, Universidade Federal do Paraná UFPR, Rua dos Funcionários, 1540, CEP 80035-050, Curitiba, PR, Brasil. e-mail: deiabuzatti@gmail.com
} 


\section{Introduction}

Haemonchus contortus is a hematophagous gastrointestinal parasite of ruminants that is extremely important on a global scale. It is one of the most prevalent parasites, causing a lot of damage to animals, thereby having a substantial impact on farm production. The parasite has been reported to outlive the use of different anthelmintic products (FORTES \& MOLENTO, 2013)

Phage display is a low-cost and fast method for mapping the epitope of an antigen that is involved in a specific protein interaction with the antibody. The identification of epitopes is essential in diagnostics, immunotherapy, drug discovery and vaccine development to combat diseases (PANDE et al., 2010). This application, enables selection of mimotopes, peptides mimicking natural epitopes of a pathogen, even without prior knowledge of the natural ligand area (ELLIS et al., 2012).

Concerning parasite control, phage display library technology is still a relatively novel research area (ELLIS et al., 2012) and it has not been applied previously in the screening of $H$. contortus mimotopes.

Several reports have demonstrated the use of phage display libraries for targeting and diagnosis of parasites (HELL et al., 2009; GAZARIAN et al., 2012; CHEONG et al., 2016; RHAIEM \& HOUIMEL, 2016), and promising studies on protective mimotopes have been reported on Plasmodium falciparum (ADDA et al., 1999), Schistosoma japonicum (TANG et al., 2004), Trichinella spiralis (GU et al., 2008), Fasciola hepatica (VILLA-MANCERA et al., 2008), Rhipicephalus (Boophilus) microplus (PRUDENCIO et al., 2010), and Taenia solium (ASSANA et al., 2010). The objective of this study was to evaluate for the first time, the use of phage display technology for mapping $H$. contortus mimotopes.

\section{Materials and Methods}

\section{Haemonchus contortus polyclonal antibodies}

Forty-eight adult sheep from a herd naturally infected with $H$. contortus and exposed to repeated infections, were used to obtain serum. We selected serum only from the animals with high IgG titter and zero parasite fecal egg count (FEC).

Blood samples $(10 \mathrm{ml})$ were collected from the jugular vein of all animals. The serum was separated by centrifugation at 3000 $\mathrm{x} g$ for $10 \mathrm{~min}$ and stored at $-20^{\circ} \mathrm{C}$ until its use for the ELISA and biopanning assays.

\section{Extraction of Haemonchus contortus proteins}

Fifty worms were crushed in liquid nitrogen using a mortar and pestle. Protein extraction was performed using chilled $0.1 \%[\mathrm{v} / \mathrm{v}] \mathrm{PBS}$ and Tween 20, with shaking for $1 \mathrm{~h}$ at $4^{\circ} \mathrm{C}$. The samples were centrifuged at $10,000 \mathrm{x} \mathrm{g}$ for $20 \mathrm{~min}$ at $4^{\circ} \mathrm{C}$. The supernatant was filtered and aliquots were kept at $-20^{\circ} \mathrm{C}$ until use. The protein concentration was determined by Qubit protein assay (Invitrogen, USA).

\section{Enzyme-linked immunosorbent assay (ELISA)}

The 96-well ELISA plates (PolySorp, Nunc) were coated with $5 \mu \mathrm{g} \mathrm{ml}^{-1}\left(100 \mu \mathrm{l}\right.$ well $\left.{ }^{-1}\right)$ of $H$. contortus total proteins (DÍAZ et al., 2015) $\left(5 \mu \mathrm{g} \mathrm{ml}^{-1}\right.$ of chemically-synthesized peptides or $10^{11}$ plaque-forming units or $5 \mu \mathrm{g} \mathrm{m}^{-1}$ according to the assay) diluted in coating buffer $(0.1 \mathrm{mM}$ sodium carbonate-bicarbonate, $\mathrm{pH}$ 9.6) and incubated at $4^{\circ} \mathrm{C}$ overnight. The plates were washed four times with $0.05 \%$ [v/v] Tween 20 solution (Merck, USA). The blocking of the reaction was performed with 3\% [v/v] PBS for $1 \mathrm{~h}$ at $20^{\circ} \mathrm{C}$. The plates were washed four times with $0.05 \%$ [v/v] Tween 20 solution. Sheep sera were used at 1:100, 1:300, $1: 600,1: 1200,1: 2400,1: 4800,1: 9600$ and 1:19200, depending on the assay, in PBS $1 \times 0.2 \%[\mathrm{v} / \mathrm{v}$ ] Tween 20 and incubated for $1 \mathrm{~h}$ at room temperature. After incubation, the plates were washed four times with Tween 20 solution $0.05 \%$ [v/v] and the anti-sheep IgG HRP 1:10.000 (Sigma A3415) was added. The plates were washed four times with $0.05 \%$ [v/v] Tween 20 solution and ABTS [2,2'-azino-bis(3-ethylbenzothiazoline-6-sulphonic acid)] buffer was added. The plates were then incubated in the dark at $20^{\circ} \mathrm{C}$ for $30 \mathrm{~min}$. The optical density was determined using a microplate reader (BioTek, USA) at $405 \mathrm{~nm}$. The cut-off optical density (OD) was determined using the mean OD + 3xSD (standard deviation) of the negative control (serum of sheep not infected with $H$. contortus).

\section{Titration, purification and amplification of the phage}

The PhD-7 Phage Display Peptide Library Kit (New England BioLabs, USA) was used according to methodology previously described by Wu et al. (2006). The technology consists of a randomized linear 7-mer peptides fused to a minor coat protein (pIII) of M13 phage.

\section{Peptide selection from Phage-Display Library}

A 96-well plate (PolySorp, Nunc) was coated with IgG protein-G purified from sheep polyclonal sera that recognized $H$. contortus (1:100), in $100 \mu \mathrm{l}$ of binding buffer (0.1M NaHCO3, $\mathrm{pH}$ 9.6), overnight at $4^{\circ} \mathrm{C}$. The panning process was performed according to Wu et al. (2006).

Four rounds of selection were performed, after which an individual plaque was picked up at random and subjected to analysis by ELISA and DNA sequencing, following amplification in Escherichia coli ER2537.

\section{Analysis of the selected clones}

After the four selection rounds, each clone obtained had its DNA purified and sequenced using a capillary electrophoresis apparatus (ABI3130) using BigDye ${ }^{\circledR}$ terminator v 3.1 and POP 7 polymer. The sequence analyses were carried out using the software Vector NTI (version 6.0) and Molecular Evolutionary Genetics Analysis (version 6.06). We evaluated the identity among the clones and also with $H$. contortus protein sequences available in GenBank. 


\section{Evaluation of peptides as mimotopes}

Serum samples of 25 sheep naturally infected with $H$. contortus were subjected to ELISA testing (section 2.3) to evaluate the peptides' abilty as mimotopes. The plates were coated with two chemically-synthesized peptides, which had the same sequences and confomation (7 amino acids - aa) displayed on two clones selected by the biopanning, and used in the vaccination assay.

\section{Immunization protocol}

To evaluate the potential of the selected mimotopes as experimental vaccine candidates, two clones displaying the peptides were selected to perform the in vivo study. Clone 6 - similar to the glyceraldehyde-3-phosphate dehydrogenase (GAPDH) and clone 17 - similar to a disorganized muscle family member (Dim 1) were used. Twelve sheep, 8-10 months old, raised indoors under nematode-free conditions, were allocated into 3 groups of 4 animals as follows: G1: control group - infected but not immunized; G2: GAPDH - immunized with clone 6; and G3: Dim 1 - immunized with clone 17. Vaccinated animals were immunized with $5 \times 10^{11} \mathrm{pfu}$ with the adjuvant Montanide ISA $25 \mathrm{VG}$ according to the manufacturer's recommendations. G1 was unvaccinated but received $1 \mathrm{ml}$ of the same adjuvant. Four immunizations were performed at seven-day intervals $(0$, 7,14 and 21 days). On day 28 post-vaccination, all groups were orally challenged with 2500 infective $H$. contortus larvae (L3). All sheep were humanely slaughtered on day 63 .

\section{Serological analysis}

Sheep serum samples, corresponding to days $0 ; 14 ; 21 ; 28$; 44; 51; and 63 were used for testing antibody response (ELISA section 2.3). All samples were examined against five antigens: 1 : M13 phage, 2: Clone 6, 3: Clone 17, 4: chemically-synthesized GAPDH (7 aa), and 5: chemically-synthesized Dim 1 (7 aa).

\section{Haematological analysis}

Blood samples were collected on day $0 ; 14 ; 28 ; 44$ and 50 following the first vaccination, by jugular venipuncture into vaccum glass tubes containing EDTA as anti-coagulant. The samples were used for leukogram and haemoglobin determination. Differential cell counts were also carried out.

\section{Fecal egg count (FEC)}

Fecal samples were collected from each sheep at day 0; 28; 44; 47; 51 and 55 of the experiment. FEC was determined by a modified Gordon \& Whitlock (1939) method, with a sensivity of 25 eggs per gram of feces. Previously the experiment start (day 0), we analyzed fecal samples of all animals for 4 consecutive days (day -4 ; day -3; day -2 and day -1) to confirm the absence of infection by gastrointestinal parasites.

\section{Abomasum worm counts}

The number of worms in the abomasum from all slaughtered animals was determined on day 63. The abomasal content was collected and the mucosa was scraped and washed with warm $0.9 \%$ sodium chloride to detach the worms. All $H$. contortus were picked up, collected, counted and sorted according to their sex.

All protocols were approved by the Animal Care and Ethics Committee of Camaguey University, Cuba (protocol No. 2013001).

\section{Statistical analyses}

The data were analyzed using the Shapiro-Wilk normality test. The Kruskal-Wallis test was used to evaluate differences between groups $(\mathrm{P}<0.05)$.

\section{Results}

\section{Phage display library biopanning}

To map the epitopes of $H$. contortus, a random heptapeptide phage display library $(\mathrm{PhD}-7)$ comprised of $1.0 \times 10^{12}$ independent phage clones was screened with the coated sheep polyclonal antibodies (H. contortus- $\operatorname{IgG}$ ). After four rounds of biopanning, the selected phage bound to $H$. contortus-IgG were well enriched (2100X), as indicated by the increased recovery. The number of phage peptides bound to $H$. contortus-IgG increased from $2.2 \times 10^{4}$ pfu in the first round to $4.6 \times 10^{7}$ pfu in the fourth round.

After four rounds of selection, 50 peptide phage clones were selected by biopanning and sequenced by capillary electrophoresis. The analysis of the sequences (Figure 1) revealed degrees of identity among some clones and also to proteins of $H$. contortus, namely, Glyceraldehyde-3-phosphate dehydrogenase (GAPDH) and a Disorganized Muscle Family Member (Dim 1).

The identity among clones 9; 10 and 32 was $100 \%$; and among the clones $21 ; 25 ; 26 ; 37 ; 39$ and 40 was $57.14 \%$. The identity between GAPDH and clone 6 was $71.42 \%$; the identity among Dim1, clone 11 and clone 17 was 57.14.

\begin{tabular}{l|l} 
(a) & $\cdots$ \\
\hline 1. Clone 21 & YDMPNTV \\
\hline 1. Clone 25 & YDMHNTV \\
\hline 1. Clone 26 & YDMPNTV \\
\hline 1. Clone 37 & YDL HNTV \\
\hline 1. Clone 39 & YDMHNAV \\
\hline 1. Clone 40 & YDMPNV \\
\hline
\end{tabular}

\begin{tabular}{l|l} 
(b) & $\ldots \ldots \ldots *$ \\
\hline 1. Clone 10 & NER ALTL \\
\hline 2. Clone 32 & NERALTL \\
\hline 3. Clone 9 & NERALTL
\end{tabular}

\begin{tabular}{|c|c|c|c|}
\hline (c) & $* * *$ & (d) & $\cdot \cdots$ \\
\hline 1. GAPDH & FVSDTHS & 1. $\operatorname{Dim} 1$ & GKGNANF \\
\hline 2. Clone 6 & FLSDTRS & $\begin{array}{l}\text { 2. Clone } 17 \\
\text { 3. Clone } 11\end{array}$ & $\begin{array}{l}\text { GSGNAI M } \\
\text { GSGNAHR }\end{array}$ \\
\hline
\end{tabular}

Figure 1. Phage display technology was employed to select mimotopes of Haemonchus contortus peptides. Analyses of the phage cloned sequences were performed with MEGA software Version 6.06. Consensus sequence $\left({ }^{*}\right)$ was observed among amino acids of some clones $(\mathrm{a}, \mathrm{b})$ and also to two $H$. contortus proteins, Glyceraldehyde3-phosphate dehydrogenase (c) and a Disorganized muscle family member - Dim 1 (d). 
The evaluation of the chemically-synthesized peptides as mimotopes is demonstrated in Figure 2 ( $a$ and b). The serum samples analyzed against the peptide GAPDH (Figure 2a) revealed 24 samples with $\operatorname{IgG}$ higher than the cut-off and just one sample below the cut-off. When used against Dim 1 (Figure 2b), 12 samples demonstrated IgG means above and 12 samples below the cut-off value.

\section{Immunization trial}

Circulating antibody responses were observed in both vaccinated groups from day 14 onwards (Figure $3 \mathrm{~b}$ and $3 \mathrm{c}$ ). The same animals also revealed IgG against the M13 phage (Figure 3a). The IgG titers of the vaccinated groups were similar and followed the same pattern, rising after the first immunization (Day 0) and reaching a peak on day 28. The animals did not show an $\mathrm{IgG}$ response specifically against the GAPDH (Figure 3d) or Dim 1 (Figure 3e) chemically-synthesized peptides.

The infection with $H$. contortus was confirmed on day 44 . We did not detect any significant FEC reduction within the experimental groups; nor for the worm counts $(\mathrm{P}>0.05)$ after vaccination (data not shown). The results from leukogram and haemoglobin analyses are shown in Table 1, with a lack of significant variations during the experimental period.

(a)
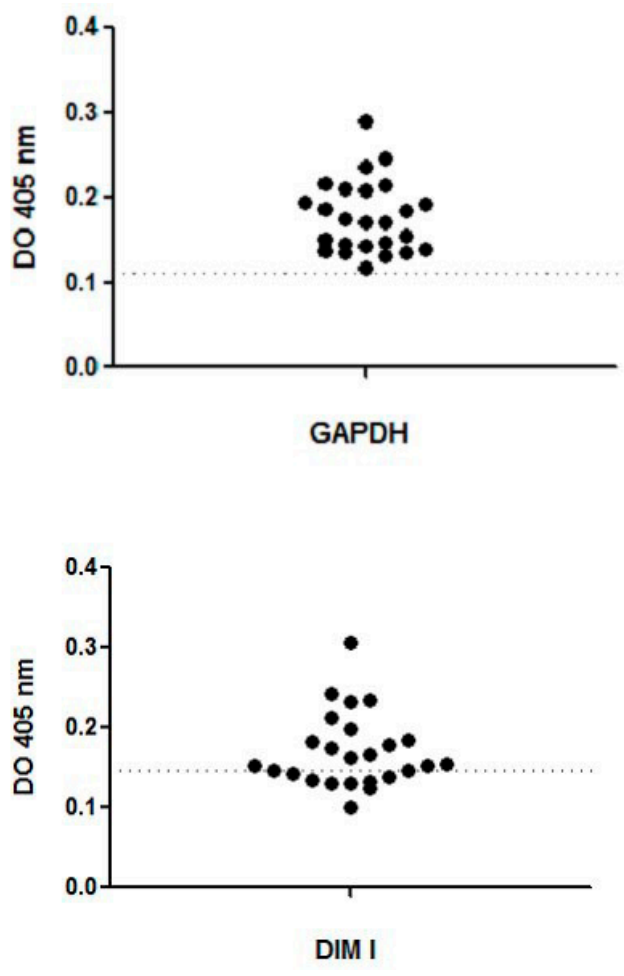

Figure 2. Mean levels of plasma IgG of 25 adult sheep naturally infected with Haemonchus contortus. The serum samples were analyzed against two chemically-synthesized peptides: (a) Glyceraldehyde-3phosphate dehydrogenase (GAPDH) and (b) Disorganized muscle family member (Dim 1). These synthetic peptides have the same sequences ( 7 amino acids) displayed on two clones ( 6 and 17, respectively) selected by biopanning.
Table 1. Hemoglobin, total leukocyte number and percentage of lymphocyte, neutrophil and eosinophil cells in blood are shown as means \pm SD. Twelve 8-10 month-old Suffolk sheep were alocated into 3 groups of 4 animals as follows: Control: infected but not immunized; GAPDH: immunized with clone 6; and Dim 1: immunized with clone 17. Four immunizations were performed (0, 7, 14 and 21 days) with $5 \times 10^{11}$ phage particles displaying mimotopes of $H$. contortus peptides - On day 28 all groups were orally challenged with 2500 infective $H$. contortus infective larvae. All groups demonstrated similar results $(\mathrm{P}>0.05)$ by the Kruskall-Wallis test.

\begin{tabular}{|c|c|c|c|}
\hline $\begin{array}{c}\text { Day of } \\
\text { experiment }\end{array}$ & GAPDH & Dim 1 & Control \\
\hline \multicolumn{4}{|c|}{ Hemoglobin $(\mathrm{g} / \mathrm{dl})$} \\
\hline Day 0 & $10.64 \pm 2.90$ & $11.90 \pm 2.92$ & $11.03 \pm 4.05$ \\
\hline Day 14 & $14.50 \pm 2.23$ & $11.66 \pm 3.82$ & $13.37 \pm 3.03$ \\
\hline Day 28 & $11.75 \pm 2.42$ & $13.52 \pm 3.97$ & $13.20 \pm 2.02$ \\
\hline Day 44 & $12.56 \pm 2.68$ & $14.73 \pm 1.68$ & $14.28 \pm 3.05$ \\
\hline Day 50 & $13.89 \pm 1.96$ & $14.41 \pm 2.06$ & $13.10 \pm 0.81$ \\
\hline \multicolumn{4}{|c|}{ Total leukocytes $\left(\right.$ x $\left.10^{3} / \mu \mathrm{L}\right)$} \\
\hline Day 0 & $11.85 \pm 2.06$ & $12.00 \pm 1.48$ & $12.12 \pm 1.42$ \\
\hline Day 14 & $12.20 \pm 2.14$ & $10.97 \pm 0.28$ & $12.12 \pm 1.38$ \\
\hline Day 28 & $11.07 \pm 1.96$ & $10.70 \pm 2.09$ & $12.50 \pm 1.58$ \\
\hline Day 44 & $11.37 \pm 1.15$ & $12.47 \pm 0.75$ & $12.27 \pm 1.61$ \\
\hline Day 50 & $12.05 \pm 2.04$ & $10.92 \pm 1.90$ & $12.57 \pm 1.19$ \\
\hline \multicolumn{4}{|c|}{ Lymphocytes (\%) } \\
\hline Day 0 & $58.75 \pm 3.86$ & $59.50 \pm 4.72$ & $57.50 \pm 2.38$ \\
\hline Day 14 & $68.00 \pm 8.16$ & $64.50 \pm 6.35$ & $66.00 \pm 6.22$ \\
\hline Day 28 & $61.00 \pm 4.08$ & $65.00 \pm 0.82$ & $61.50 \pm 1.91$ \\
\hline Day 44 & $59.25 \pm 3.30$ & $53.75 \pm 0.50$ & $56.75 \pm 6.95$ \\
\hline Day 50 & $64.25 \pm 3.77$ & $62.00 \pm 6.22$ & $60.50 \pm 2.65$ \\
\hline \multicolumn{4}{|c|}{ Neutrophil (\%) } \\
\hline Day 0 & $36.75 \pm 3.30$ & $36.75 \pm 3.77$ & $39.00 \pm 2.44$ \\
\hline Day 14 & $26.75 \pm 7.80$ & $31.00 \pm 5.35$ & $30.00 \pm 6.48$ \\
\hline Day 28 & $34.25 \pm 3.59$ & $31.00 \pm 1.56$ & $32.75 \pm 1.72$ \\
\hline Day 44 & $36.00 \pm 3.37$ & $41.25 \pm 1.73$ & $37.00 \pm 5.71$ \\
\hline Day 50 & $30.75 \pm 2.75$ & $32.75 \pm 5.44$ & $34.50 \pm 2.38$ \\
\hline \multicolumn{4}{|c|}{ Eosinophil (\%) } \\
\hline Day 0 & $2.25 \pm 0.50$ & $1.25 \pm 0.50$ & $1.50 \pm 0.58$ \\
\hline Day 14 & $2.25 \pm 0.50$ & $2.25 \pm 0.50$ & $1.75 \pm 0.96$ \\
\hline Day 28 & $1.75 \pm 0.50$ & $1.75 \pm 0.96$ & $2.75 \pm 1.26$ \\
\hline Day 44 & $1.75 \pm 0.50$ & $1.50 \pm 0.58$ & $2.25 \pm 0.50$ \\
\hline Day 50 & $2.50 \pm 0.58$ & $1.75 \pm 0.96$ & $1.75 \pm 0.50$ \\
\hline \multicolumn{4}{|c|}{ Monocytes (\%) } \\
\hline Day 0 & $1.50 \pm 1.00$ & $1.75 \pm 0.50$ & $1.50 \pm 0.58$ \\
\hline Day 14 & $1.50 \pm 0.58$ & $1.25 \pm 0.50$ & $1.75 \pm 0.50$ \\
\hline Day 28 & $2.00 \pm 0.82$ & $1.50 \pm 0.58$ & $2.00 \pm 0.82$ \\
\hline Day 44 & $2.00 \pm 0.82$ & $1.75 \pm 0.50$ & $1.75 \pm 0.96$ \\
\hline Day 50 & $1.75 \pm 0.50$ & $1.50 \pm 0.58$ & $1.25 \pm 0.50$ \\
\hline \multicolumn{4}{|c|}{ Basophils (\%) } \\
\hline Day 0 & $0.25 \pm 0.50$ & $0.50 \pm 0.58$ & $0.50 \pm 0.58$ \\
\hline Day 14 & $1.25 \pm 0.96$ & $0.75 \pm 0.96$ & $0.50 \pm 0.58$ \\
\hline Day 28 & $0.75 \pm 0.50$ & $0.50 \pm 0.58$ & $0.00 \pm 0.00$ \\
\hline Day 44 & $0.50 \pm 0.58$ & $0.75 \pm 0.96$ & $1.50 \pm 0.58$ \\
\hline Day 50 & $0.25 \pm 0.50$ & $1.50 \pm 0.58$ & $1.25 \pm 0.96$ \\
\hline
\end{tabular}



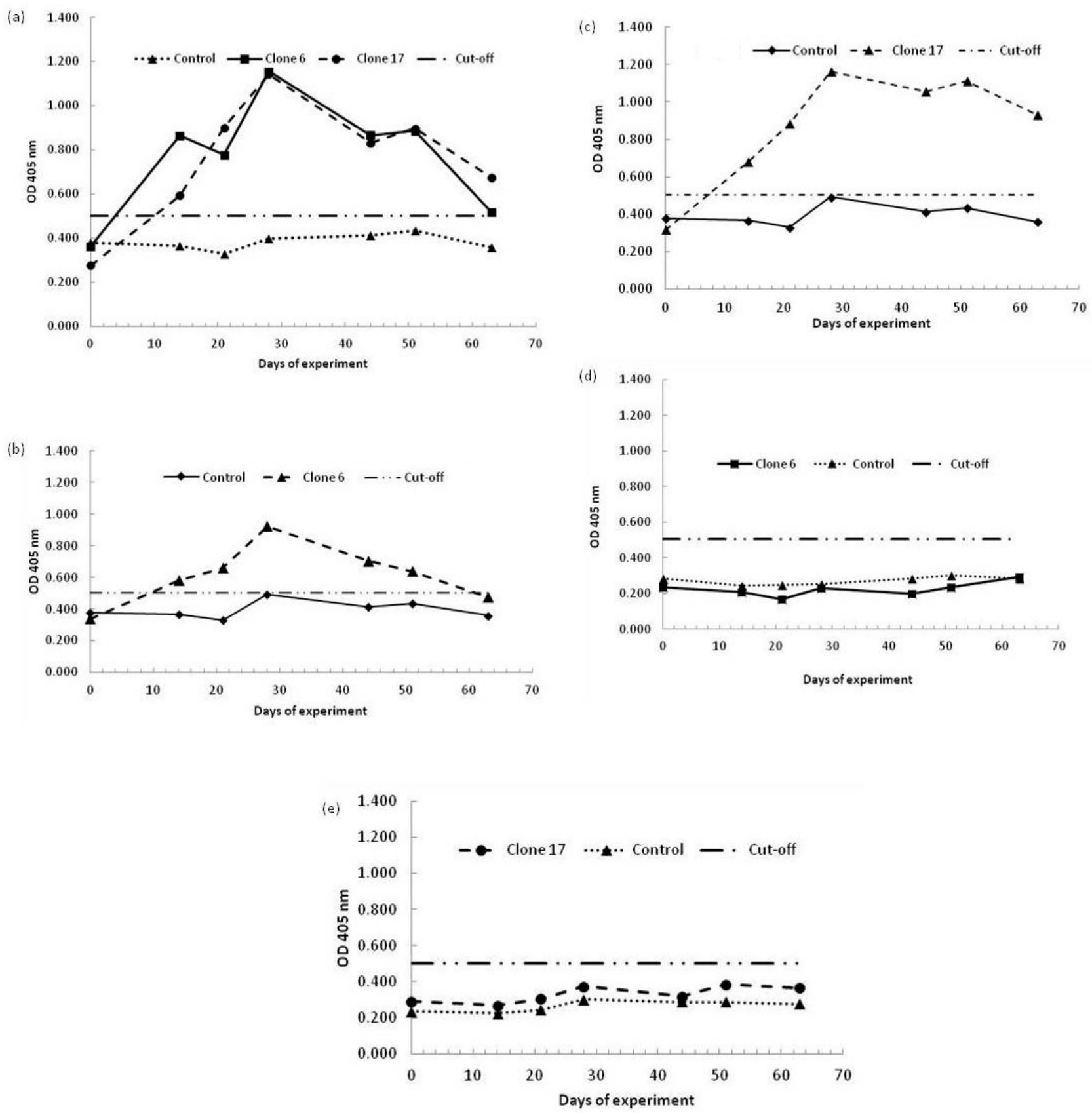

Figure 3. Mean levels of plasma IgG of sheep against M13 phage (a), Clone 6 (b), Clone17 (c), Chemically-synthesized GAPDH mimotope (d) and Chemically-synthesized Dim 1 mimotope (e). Twelve 8-10 month-old Suffolk sheep were allocated into 3 groups of 4 animals as follows: Control: infected but not immunized; GAPDH: immunized with clone 6; and Dim 1: immunized with clone 17. Four immunizations were performed $\left(0,7,14\right.$ and 21 days) with $5 \times 10^{11}$ phage particles displaying mimotopes of $H$. contortus peptides - Clone 6 displayed a mimotope of Glyceraldehyde-3-phosphate dehydrogenase (GAPDH) and the clone 17 a mimotope of a Disorganized muscle family member (Dim 1).

\section{Discussion}

This is the first study using phage display to select $H$. contortus peptide mimotopes. This technology allowed mimotope selection for displayed peptides, using polyclonal serum of sheep naturally infected with $H$. contortus. The molecules bound to pathogen antibody are antigenic mimotopes of the pathogen (GAZARIAN et al., 2011). The ability of selected peptides to act as antigenic mimotopes was confirmed by serum analyzes against chemical peptides (GAPDH and/or Dim 1). We observed that IgG of animals naturally infected were able to recognize and bind to these peptides. The best results were for GAPDH, where only one sample had an IgG titre less than the cut-off.

In this study, after four selection rounds of biopanning, the bioinformatic analysis revealed two phage clones containing peptides with homology to GAPDH (clone 6) and Dim 1 (clone 17) proteins 
of $H$. contortus. Researchers have analyzed the immunogenic potential of many $H$. contortus molecules and immunoproteomic studies have already demonstrated that 23 immunogenic proteins are shared between males and females of $H$. contortus. These molecules include homologous of Dim 1 and GAPDH, among others (YAN et al., 2010).

GAPDH and Dim 1 are important vaccine candidates. In addition to their immunogenic potential, they perform important functions at cellular level. GAPDH is an enzyme crucial for energy production, in glycolysis and glyconeogenesis (NICHOLLS et al., 2012). It has also been related to other intracellular (SIROVER, 2011) and extracellular (GÓMEZ-ARREAZA et al., 2014) functions. According to Han et al. (2012), this molecule is a major therapeutic candidate for vaccines and a target for chemotherapy treatment against several parasites. Dim 1 is a structural protein located in the muscle cell membrane region, around and between dense bodies. It performs a key role in stabilizing the thin filament components of the sarcomere (YAN et al., 2013). Thus, an immunological response generated against these molecules might protect the animals against $H$. contortus infection.

In the in vivo assay, animals of both immunized groups GAPDH and Dim 1 presented IgG titers against M13 phage. The IgG increase followed the same pattern in both GAPDH and Dim 1 groups, with a peak after the last immunization. However, despite the sequence similarities to the immunogenic molecules of $H$. contortus (YAN et al., 2010), the peptides displayed by the phage did not promote specific IgG titers. It is important to note that the sequence displayed on the phage surface consisted of only 7 amino acids in linear conformation, being a small peptide compared to the full phage surface. Cui et al. (2013) observed significant immune responses and protection against $T$. spiralis infection in mice immunized with phage. However, they used a recombinant phage system, which displayed a 202-aa polypeptide.

To date, sheep immunization with phage displaying mimotopes has been reported only for F. hepatica. For this, animals were immunized at week 0 and 2 with $1 \times 10^{14}$ phage particles expressing 7-aa mimotopes and challenged with 300 metacercariae, 4 weeks after immunization. The mean worm burden was reduced by $47.61 \%$ and the egg viability from 58.92 to $82.11 \%$. The animals produced specific antibodies after the metacercariae challenge (VILLA-MANCERA et al., 2008).

Another study with a similar design had sheep receiving $1 \times 10^{13}$ phage particles (12-aa mimotopes) and challenged with 300 metacercariae 4 weeks later. The worm burdens and FEC were reduced by 51.7 and $45.7 \%$, respectively (VILLA-MANCERA \& MÉNDEZ-MENDOZA, 2012). In our work, the animals were immunized with phage expressing mimotopes of GAPDH or Dim 1 (7aa) but there was no reduction in FEC or worm counts, indicating the absence of a protective effect. A DNA vaccine encoding Dim 1 antigen against $H$. contortus reduced the FEC and worm counts of goats by 47.5 and $51.1 \%$ respectively (YAN et al., 2013). Similarly, a GAPDH DNA vaccine reduced FEC and worm count by 34.9 and $37.7 \%$, respectively (HAN et al., 2012). These studies support the immunogenic potential of these molecules.

Eosinophils also have an important function in immune responses against helminth infections, and are often associated with resistance to parasite infections in sheep (PFEFFER et al., 1996;
PATNODE et al., 2014). In our work, eosinophils and the other leukogram parameters did not reveal any difference throughout the experimental period. Yan et al. (2014) evaluating a $H$. contortus actin DNA vaccine in goats failed to detect differences in the eosinophil, neutrophil, basophil and monocyte counts before L3 challenge. However, after the challenge of 5000 L3 infective $H$. contortus, only eosinophil counts were significantly increased.

Santos et al. (2014) tested a single infection with $4000 \mathrm{~L} 3$, and one week later the challenged groups presented significantly higher eosinophil numbers. However, there was a gradual decline in the average values, until the end of the trial. In the same experiment, they observed an increase in the eosinophil average in serially infected groups (3 times a week, from day $0-25$ of the trial with 500 L3). Values significantly higher than the control group were observed on days $14,21,25,28$, and 32 with the peak of eosinophil counts on day 25 . They concluded that the animals developed this high protection after being consecutively challenged with $H$. contortus. The authors reported that immunity against the parasite was not easily elicited other than after the prolonged infection. In our study, we used a single challenge infection with $2500 \mathrm{~L} 3$, and that may have been reflected in the failure to see an increase in eosinophil counts.

It is important to emphasize that the development of immunity to $H$. contortus antigens is complex and highly variable. It depends on the host-parasite interaction, which is influenced by many factors, following an intrinsic and extrinsic relationship (TAK et al., 2015; NISBET et al., 2016). In our trial, the two mimotopes selected by phage display failed to protect, and neither induced a distinct immune response in the animals. The peptides reacted with polyclonal antibodies in serum from sheep naturally infected with $H$. contortus, but were not immunogenic when carried by the M13 phage, even though the two selected clones had high sequence similarity to Dim 1 and GAPDH of $H$. contortus. Our data highlight the importance of new studies to evaluate specific peptides from parasites.

\section{Conclusion}

The phage display library was successfully used to identify $H$. contortus mimotopes. The selected clones revealed relatedness to Dim 1 and GAPDH of $H$. contortus proteins. The peptides were recognized by several sera from sheep naturally infected with $H$. contortus, indicating their potential use as a diagnostic. The sheep immunized with phage displaying the mimotopes did not develop protection against the parasite.

\section{Acknowledgements}

The authors are grateful to the Coordenação de Aperfeiçoamento de Pessoal de Nível Superior (CAPES), Universidade Federal do Paraná (UFPR), Laboratório de Produção de Ovinos e Caprinos (LAPOC), and to Universidad de Camaguey, Cuba for their support. This work was financially supported by CAPES-PVE 2015 and CNPq-Universal 2014 Brazil. 


\section{References}

Adda CG, Tilley L, Anders RF, Foley M. Isolation of peptides that mimic epitopes on a malarial antigen from random peptide libraries displayed on phage. Infect Immun 1999; 67(9): 4679-4688. PMid:10456916.

Assana E, Gauci C, Kyngdon C, Zoli A, Dorny P, Geerts S, et al. Antibody responses to the host-protective Taenia solium oncosphere protein TSOL18 in pigs are directed against conformational epitopes. Parasite Immunol 2010; 32(6): 399-405. http://dx.doi.org/10.1111/j.13653024.2009.01197.x. PMid:20500670.

Cheong FW, Fong MY, Lau YL. Identification and characterization of epitopes on Plasmodium knowlesi merozoite surface protein-142 (MSP142) using synthetic peptide library and phage display library. Acta Trop 2016; 154: 89-94. http://dx.doi.org/10.1016/j.actatropica.2015.11.005. PMid:26624919.

Cui J, Ren HJ, Liu RD, Wang L, Zhang ZF, Wang ZQ. Phage-displayed specific polypeptide antigens induce significant protective immunity against Trichinella spiralis infection in BALB/c mice. Vaccine 2013; 31(8): 1171-1177. http://dx.doi.org/10.1016/j.vaccine.2012.12.070. PMid:23306358.

Díaz A, Arenal A, França J, Gomes AL, Machado MA, Sossanovicz $\mathrm{M}$, et al. Optimization of an immunoenzymatic (ELISA) assay for detecting ovine antibodies against Haemonchus contortus. Cuban J Agr Sci 2015; 49(4): 477-485.

Ellis SE, Newlands G, Nisbet A, Matthews J. Phage-display library biopanning as a novel approach to identifying nematode vaccine antigens. Parasite Immunol 2012; 34(5): 285-295. http://dx.doi.org/10.1111/j.13653024.2011.01317.x. PMid:21770973.

Fortes FS, Molento MB. Resistência anti-helmíntica em nematoides gastrintestinais de pequenos ruminantes: avanços e limitaçóes para seu diagnóstico. Pesq Vet Bras 2013; 33(12): 1391-1402. http://dx.doi. org/10.1590/S0100-736X2013001200001.

Gazarian K, Gazarian T, Betancourt JI, Alonso Morales RA. Immunogenic peptides from phage display libraries with potential of protecting mice against the Pseudorabies virus. J Vet Microbiol 2011; 154(1-2): 29-36. http://dx.doi.org/10.1016/j.vetmic.2011.06.020. PMid:21764227.

Gazarian K, Rowlay M, Gazarian T, Vazquez Buchelli JE, Hernández Gonzáles M. Mimotope peptides selected from phage display combinatorial library by serum antibodies of pigs experimentally infected with Taenia solium as leads to developing diagnostic antigens for human neurocysticercosis. Peptides 2012; 38(2): 381-388. http://dx.doi. org/10.1016/j.peptides.2012.09.021. PMid:23022592.

Gómez-Arreaza A, Acosta H, Quiñones W, Concepción JL, Michels PA, Avilán L. Extracellular functions of glycolytic enzymes of parasites: unpredicted use of ancient proteins. Mol Biochem Parasitol 2014; 193(2): 75-81. http://dx.doi.org/10.1016/j.molbiopara.2014.02.005. PMid:24602601.

Gordon HM, Whitlock HV. A new technique for counting nematode eggs in sheep faeces. J Sci Ind Res 1939; 12(1): 50-52.

Gu Y, Li J, Zhu X, Yang J, Li Q, Liu Z, et al. Trichinella spiralis: Characterization of phage-displayed specific epitopes and their protective immunity in BALB/c mice. Exp Parasitol 2008; 118(1): 66-74. http:// dx.doi.org/10.1016/j.exppara.2007.06.014. PMid:17707815.

Han K, Xu L, Yan R, Song X, Li X. Vaccination of goats with glyceraldehyde3-phosphate dehydrogenase DNA vaccine induced partial protection against
Haemonchus contortus. Vet Immunol Immunopathol 2012; 149(3-4): 177185. http://dx.doi.org/10.1016/j.vetimm.2012.06.016. PMid:22771197.

Hell RC, Amim P, Andrade HM, Avila RA, Felicori L, Oliveira AG, et al. Immunodiagnosis of human neurocysticercosis using a synthetic peptide selected by phage-display. Clin Immunol 2009; 131(1): 129-138. http:// dx.doi.org/10.1016/j.clim.2008.10.012. PMid:19186111.

Nicholls C, Li H, Liu JP. GAPDH: a common enzyme with uncommon functions. Clin Exp Pharmacol Physiol 2012; 39(8): 674-679. http://dx.doi. org/10.1111/j.1440-1681.2011.05599.x. PMid:21895736.

Nisbet AJ, Meeusen EN, González JF, Piedrafita DM. Immunity to Haemonchus contortus and Vaccine Development. Adv Parasitol 2016; 93: 353-396. http://dx.doi.org/10.1016/bs.apar.2016.02.011. PMid:27238008.

Pande J, Szewczyk MM, Grover AK. Phage display: Concept, innovations, applications and future. Biotechnol Adv 2010; 28(6): 849-858. http:// dx.doi.org/10.1016/j.biotechadv.2010.07.004. PMid:20659548.

Patnode ML, Bando JK, Krummel MF, Locksley RM, Rosen SD. Leukotriene B4 amplifies eosinophil accumulation in response to nematodes. $J$ Exp Med 2014; 211(7): 1281-1288. http://dx.doi.org/10.1084/jem.20132336. PMid:24889202.

Pfeffer A, Douch P, Shaw R, Gatehouse T, Rabel B, Green R, et al. Sequential cellular and humoral responses in the abomasal mucosa and blood of Romney sheep dosed with Trichostrongylus axei. Int J Parasitol 1996; 26(7): 765-773. http://dx.doi.org/10.1016/0020-7519(96)000525. PMid:8894768.

Prudencio CR, Marra AO, Cardoso R, Goulart LR. Recombinant peptides as new immunogens for the control of the bovine tick, Rhipicephalus (Boophilus) microplus. Vet Parasitol 2010; 172(1-2): 122-131. http:// dx.doi.org/10.1016/j.vetpar.2010.04.012. PMid:20488622.

Rhaiem RB, Houimel M. Targeting Leishmania major parasite with peptides derived from a combinatorial phage display library. Acta Trop 2016; 159: 11-19. http://dx.doi.org/10.1016/j.actatropica.2016.03.018. PMid:26995695.

Santos MC, Xavier JK, Amarante MRV, Bassetto CC, Amarante AFT. Immune response to Haemonchus contortus and Haemonchus placei in sheep and its role on parasite specificity. Vet Parasitol 2014; 203(1-2): 127 138. http://dx.doi.org/10.1016/j.vetpar.2014.02.048. PMid:24670867.

Sirover MA. On the functional diversity of glyceraldehyde-3-phosphate dehydrogenase: biochemical mechanisms and regulatory control. Biochim Biophys Acta 2011; 1810(8): 741-751. http://dx.doi.org/10.1016/j. bbagen.2011.05.010. PMid:21640161.

Tak IR, Dar JS, Dar SA, Ganai BA, Chishti MZ, Ahmad F. A comparative analysis of various antigenic proteins found in Haemonchus contortus - a review. Mol Biol (Mosk) 2015; 49(6): 883-890. http://dx.doi.org/10.1134/ S0026893315060217. PMid:26710767.

Tang LF, Yi XY, Zeng XF, Wang LQ, Zhang SK. Schistosoma japonicum: Isolation and identification of peptides mimicking ferritin epitopes from phage display library. Acta Biochim Biophys Sin (Shanghai) 2004; 36(3): 206-210. http://dx.doi.org/10.1093/abbs/36.3.206. PMid:15202505.

Villa-Mancera A, Méndez-Mendoza M. Protection and antibody isotype responses against Fasciola hepatica with specific antibody to pIII-displayed peptide mimotopes of cathepsin L1 in sheep. Vet J 2012; 194(1): 108112. http://dx.doi.org/10.1016/j.tvjl.2012.03.003. PMid:22513301.

Villa-Mancera A, Quiroz-Romero H, Correa D, Ibarra F, Reyes-Pérez M, Reyes-Vivas H, et al. Induction of immunity in sheep to Fasciola hepatica with mimotopes of cathepsin L selected from a phage display library. 
Parasitology 2008; 135(12): 1437-1445. http://dx.doi.org/10.1017/ S003118200800471X. PMid:18812010.

Wu HW, Hu XM, Wang Y, Kurtis JD, Zeng FJ, McGarvey ST, et al. Protective immunity induced by phage displayed mitochondrial related peptides of Schistosoma japonicum. Acta Trop 2006; 99(2-3): 200-207. http://dx.doi.org/10.1016/j.actatropica.2006.08.006. PMid:16999929.

Yan F, Xu L, Liu L, Yan R, Song X, Li X. Immunoproteomic analysis of whole proteins from male and female adult Haemonchus contortus. Vet J2010; 185(2): 174-179. http://dx.doi.org/10.1016/j.tvjl.2009.05.021. PMid:19560953.
Yan R, Sun W, Song X, Xu L, Li X. Vaccination of goats with DNA vaccine encoding Dim-1 induced partial protection against Haemonchus contortus: A preliminary experimental study. Res Vet Sci 2013; 95(1): 189-199. http://dx.doi.org/10.1016/j.rvsc.2013.02.020. PMid:23545480.

Yan R, Wang J, Xu L, Song X, Li X. DNA vaccine encoding Haemonchus contortus Actin induces partial protection in Goats. Acta Parasitol 2014; 59(4): 698-709. http://dx.doi.org/10.2478/s11686-014-0298-z. PMid:25236283. 